\title{
Deconstruction Of Deliberation Implementation And The Populist Meaning In The Perspective Of Prophetic Democracy In The Implementation Of Pancasila
}

\author{
Megawati \\ Universitas Ahmad Dahlan \\ megawati@law.uad.ac.id \\ DOI : https://doi.org/10.23917/jtl.v1i1.8695
}

\section{Submission \\ Track:}

Received:

10 May 2019

Final Revision:

20 June 2019

Available online:

29 June 2019

Corresponding

Author:

Megawati

megawati@law.uad.ac.id

\section{ABSTRACT}

Purpose of the study: This article aims at evaluating the implementation of popular sovereignty as a forum for deliberation in the election of regional heads as the implementation of the fourth precept of Pancasila.

Methodology: This study was conducted by using the method of descriptive philosophical normative study. As a secondary legal material, this paper garnered information from literature, papers, journals, and other related studies.

Main Findings: In the implementation of general election of regional heads, democracy in Article 18 paragraph (4) of the 1945 Constitution is not limited to direct or indirect election by the people. The election of regional heads can be carried out in conformity to the identity of Indonesia people.

Applications of this study: This study can be beneficial to the government in reexamining the policy of the direct regional head general election considering that in the interpretation of Article 18 paragraph (4) of the 1945 Constitution, general election does not have to be implemented directly.

The policy of the direct regional head general election

Novelty/Originality of this study: The notion as regards the implementation of the indirect regional head general election will have a less negative impact compared to the direct election. 


\section{INTRODUCTION}

Non-systemic jurisprudence provides different meaning making of Pancasila. The views given to Pancasila generate interpretations that are far from the essence of Pancasila as a whole and holistic unity, extending to the unity in a meaningful and related way. The context of meaning making in this regard is of very importance because Pancasila is often viewed as one of the foundations of the jurisprudence development in Indonesia. Thus, it is necessary to change the meaning making of the Pancasila text from which it was at first discerned in a single, certain, and absolute way into a way that Pancasila has the values containing a very high plurality. ${ }^{1}$

Kuntowijoyo's view as regards Pancasila states that historically Pancasila had already experienced the periods of myth and ideology. Pancasila had experienced a decay of meaning when it became an ideological narration since the early period we learned to realize democracy until the main figure of Orde Baru abdicated his power. ${ }^{2}$

The basis of the popular sovereignty contained in the fourth precept of Pancasila, which mentions "Democracy guided by the inner wisdom in the unanimity arising out of deliberations amongst representatives", infers that popular sovereignty is the essence of democracy pursuant to Pancasila. However, in practice, the democracy on the basis of popular sovereignty is definitely imbued with and integrated into other precepts. Democracy containing the values of Pancasila should be understood and implemented as citizens can take part in together, national, and societal lives.

Thus, Pancasila contained in the Preamble of the 1945 Constitution has given a philosophical view concerning with Indonesia as a modern democratic state of law (democratische rechstaat), namely a democratic state based upon law (constitutional democracy). ${ }^{3}$ See the fourth paragraph of the Preamble of the 1945 Constitution, which mentions: "The National Independence of Indonesia is formed in the composition of the Republic of Indonesia that has popular sovereignty". This point emphasizes that democracy is

\footnotetext{
${ }^{1}$ Anton F. Susanto, Non Systemic Jurisprudence, The Philosophical Foundation of Indonesian Jurisprudence Development, Yogyakarta, Genta Publishing, 1st Print, 2010, p. 301

${ }^{2}$ Absori, et al, Prophetic Legal Paradigm: The Criticism of Non-Systemic Legal Paradigm, Yogyakarta, Genta Publishing, the First Print, 2015, P. 127

${ }^{3}$ Agussalim Andi Gadjong, Local Government; the Study of Politics and Law, Bogor, Ghalia Indonesia, 2007, P. 36
} 
adhered together with the principles of a constitutional state. ${ }^{4}$ Democracy is selected based on human dignity and equality. ${ }^{5}$

Democracy or popular sovereignty is a state concept that has received much attention at present. Diverse from the autocracy or authoritarian system, it receives less attention. A country is considered to run a democracy if its law formation is executed democratically. ${ }^{6}$

It is necessary to be understood that Indonesia is known as a plural or heterogeneous country. Hence, the basic principle of the unitary state of the Republic of Indonesia, that is contained in Article 1 paragraph (1) of the 1945 Constitution; "Indonesia is a unitary state in the form of a republic", provides reinforcement for all regions as the part of the unitary state of the Indonesian Republic.

Since the beginning, the founders of the Indonesian Republic have directed at the form of the unitary state. The unitary state concept as stipulated in Article 1 paragraph (1) of the 1945 Constitution; Indonesia is a unitary state in the form of a republic, becomes the basis of the regional governmental administration by adopting a decentralized system which is further regulated in Article 18 of the 1945 Constitution. In paragraph (4) of the 1945 Constitution, it is stated that Governors, Regents, and Mayors respectively representing the regional governmental heads of province, regency, and city are elected democratically. The aforementioned statement shows that the regions have authority to hold their government. Authority $^{7}$ does not mean to be without restrictions because local governments are the constituents of the national government territory. In other words, there is no "any state within a state". It is on account of that Indonesia is a unitary state in the form of a republic as stated in Article 1 paragraph (1) of the 1945 Constitution.

As a follow-up to Article 18 of the 1945 Constitution, Law Number 32 of 2004 concerning regional government was arisen in lieu of Law Number 22 of 1999 which was not valid any longer, and the Law on regional government has presently been renewed with Law No. 23 of 2014. The purpose of the regional government is to direct it to accelerate the embodiment of community welfare through improving services, empowerment and community participation, and increasing regional competitiveness by taking account of the principles of democracy, equity, justice, and the uniqueness of a region within the unitary

\footnotetext{
${ }^{4}$ Janedjri M. Gaffar, Constitutional Democracy of Indonesian Constitutional Practices after the Amendment of the 1945 Constitution, Jakarta, Konstitusi Press, 2013, P. 38

${ }^{5}$ Jimly Asshiddiqie, Towards a Democratic Law State, Jakarta, PT Bhuana Ilmu Populer, Gramedia Group, 2009, P. 298

${ }^{6}$ Hans Kelsen, General Theori of Law and State, Russell \& Russell, N.Y., 1961, P. 283-284

${ }^{7}$ Ateng Syafrudin, The Focus of Regional Autonomy on Second Level Regions and Their Development, Mandar Maju, Bandung, 1991, Second Print, P. 131
} 
state system of the Indonesian Republic. This is mentioned in the consideration of Law No. 23 of 2014 .

The enactment of regional government regulated in Law No. 23 of 2014 is an implementation of Article 18 Paragraph (4) of the 1945 Constitution, in which it states that the regional heads are elected democratically in order to realize the improvement of regional competitiveness by taking into account the principles of democracy. Grounded in the statement of the aforementioned article, it is clear that the regional heads are no longer appointed or elected by means of a representative mechanism (DPRD) but directly elected by the people.

Therefore, with direct election of the regional heads and the deputies (in Indonesian term as Pilkada), it will theoretically bring improvements to the quality of democracy. In this regard, the direct election is expected to: (1) increase the accountability of the regional government implementation; (2) grow the maturity of political parties at the local level; (3) support the embodiment of ideal checks and balances between the Regional People's Representative Council (In Indonesian term as DPRD) and the regional heads. Nonetheless, in practice, it turns out that the direct implementation of the local elections results in various negative impacts and many excesses. ${ }^{8}$

Practically, the direct election of regional heads as such is relatively ineffective and inefficient. This is because too many things must be provided by the regions in regard to organizing the election of the regional heads. Those things are such as security against the probable conflicts that will disrupt the stability of regions, the funds that need to be spent which are quite large compared to the funds allocated for the development of regional economic potential, and many more things that are inseparable from the attention of the regional government and the community.

Thus, the thoughts vis-a-vis the form of regional head selection, especially for the regional heads at the provincial level are necessary in order to avoid various deviations by continuing to uphold the values of deliberation and the democratic meaning in the perspective of democracy as the implementation of the fourth precept of Pancasila. Problems in the direct election of Provincial Heads can be resolved by finding a new format with a hope that it generates qualified and democratic regional heads.

\footnotetext{
${ }^{8}$ Khudzaifah Dimyati, THE ELECTION OF REGIONAL HEADS: The Study on the Profile of the Joint Regional Head Election Administration in South Kalimantan, Journal of Legal Studies, Vol. 14, No. 2, September 2011, P. 200
} 
Regarding the direct election model for the regional heads, it is certain that the founders of the country at that time aimed at preventing Indonesia from falling into the authority of certain groups or political powers. Indonesia is owned by all Indonesian people who in their constitutional reality are recognized as sovereignty. In addition, given that Indonesia has a very large area of the country and a pluralistic composition of society, the implementation of democracy at the local level emphasizes the efficiency of the administration in the formation of regional government.

In the context of regional head election, the purpose is to elect qualified regional heads. However, in any form of regional head election, there is no any guarantee that it will result in the elected regional heads who can undertake their duties and authorities appropriately. Everything will depend on the extent of their good intention and morality.

Therefore, if regions are considered the extensions of the central government, it is feared that there will be a gap in regional development, and it will weaken the potential of regions which will affect the country's development. Moreover, when viewed in the condition of Indonesia which is full of diversity, it is then necessary to have a political relationship between the central government and regional governments in order to be able to realize the strength of the nation and state.

After the amendment to the 1945 Constitution, the principle of regional autonomy is still maintained in order that the regions of Indonesia are able to increase productivity in the tightly competitive era. In the development of state administration in Indonesia, the regulation of regional autonomy has progressed, namely as broad, real and responsible autonomy.

Basically, regional autonomy is not only to support the success of national and state life, but also to be able to accommodate the reality of the vast regional conditions and the presence of various islands separated by the ocean, as well as the people with diverse customs and cultures. The regions given autonomy should continuously pay attention to the aspects of the unitary state upholding popular sovereignty.

The foregoing is especially in this era of reform marked by the emergence of various ideas such as the idea of eliminating the unitary state and replacing it with a federal state, and various other ideas that touch the foundations of national and state life. Thus, the implementation of Pancasila precepts need to be deconstructed specifically for the fourth 
precept, namely; Democracy guided by the inner wisdom in the unanimity arising out of deliberations amongst representatives. ${ }^{9}$

The meaning of the fourth precept of Pancasila explains the essence of a democratic state. Pursuant to that precept, it is expected that there will be obtained a set of meaning that has philosophical values which can be directly implemented in the life of the nation and society. In addition, the fourth precept of Pancasila can be used as a guide to each behavioral process in the administration of government.

The foregoing is in light of that the implementation of democracy or popular sovereignty is never free from deviations. From a range of explanations highlighted above, it is interesting to be studied or discussed about the popular sovereignty of in the sense of the relationship between the people and the holders of sovereignty or the holders of the highest authority and the organizers of the state or those of sovereignty (the state). As the rationale, it is because the popular sovereignty diverts from the perception that the people are actually the holders of the highest authority in the country, not the state administrators. The state administrators tend to maintain and expand their power, so some restrictions on their power are needed.

Grounded in the description above, a main issue can be drawn to be formulated especially pertinent to the implementation of democracy or popular sovereignty as a forum for deliberation that focuses more on "how is the implementation of popular sovereignty as a forum for deliberation in the election of regional heads as the implementation of the fourth precept of Pancasila?"

\section{RESEARCH METHOD}

This study was conducted by using the method of descriptive philosophical normative study. As a secondary legal material, this paper garnered information from literature, papers, journals, and other related studies.

\section{RESULTS \& DISCUSSION}

\section{Deliberation and Democracy in the Prophetic Perspective}

Deliberation (permusyawaratan) is a form of democratic life in the nation and state. Etymologically, the term 'musyawarah' (the term of deliberation in Indonesian language) is

\footnotetext{
${ }^{9}$ Dahlan Thaib, Indonesian State Administration; Constitutional Perspective, Total Media, Yogyakarta, $1^{\text {st }}$ Print, 2009 , P. 7
} 
derived from Arabic language which means musyawarat (deliberation), negotiation, and cooperation. ${ }^{10}$ The root of the word musyawarah is $S y-, w-r$ - which originally means removing honey from the beehives. Furthermore, it develops to include everything that can be taken or removed from the other. The word musyawarah can also mean to say or to propose something, and basically the word musyawarah is used for good things. ${ }^{11}$

The other view with respect to the term musyawarah or syura commonly means it in its general meaning which entails any kind of giving advice and sharing opinions. In the meantime, in its specific meaning, syura refers to the provisions made based on the decisions of a representative group. Universally, the basis of syura is the existence of a representative group, in which the rights and accountability of the people within that group are taken to represent the overall individuals. In this regard, the opinions of those people represent the overall individuals', and their collective intentions also refer to those of the overall individuals (mukallaf). ${ }^{12}$

The term permusyawaratan (deliberation) or kedaulatan (sovereignty) is identified with democracy. Kedaulatan (sovereignty) is actually derived from Arabic language, namely from the words dala, yadulu, and daulatan or in the plural form duwal, which mean fluctuation or change. Besides it can also be interpreted as a kingdom, state, or power. ${ }^{13}$ Then, in the Arabic English dictionary compiled by F. Steinggass, the word duwal is interpreted as sovereignty. ${ }^{14}$ In the Al-Qur'an which is a reflection of the use of classical Arabic, the word daulah $^{15}$ is found in Surah Ali Imran 140: nudawiluha (him we rotate or exchange) and surah al-Hasyar verse 7 using the verb form daulatan (circulating). ${ }^{16}$

Within the execution of power in the unitary state of the Republic of Indonesia, before Indonesia became a state, it had used the principle of deliberation, which was pursuant to the popular sovereignty as the basis for carrying out community life. As stated by Padmo Wahjono, the state administration deliberation is to engage in a dialogue by paying attention to: a) community dynamics, b) everything that happens, and c) all groups. ${ }^{17}$

\footnotetext{
${ }^{10}$ Zein Badudu, General Dictionary of Indonesian Language, Jakarta, Pustaka Sinar Harapan, $1{ }^{\text {st }}$ Print 1994, 1st Print, P. 925

${ }^{11}$ M. Quraish Shihab, Insights of the Qur'an, Mizan, Bandung, Second Print, 1996, P. 469

${ }^{12}$ Muhammad Hanafi, Position of Deliberation and Democracy in Indonesia, Jurnal Cita Hukum, The Faculty of Syari'ah and Law of UIN Syarif Hidayatullah, Jakarta, Vol. 1, No. 2, December 2013, P. 228

${ }^{13} \mathrm{H}$, Mahmud Yunus, Indonesian Arabic Dictionary, Jakarta, The Foundation for Translator / Interpreter of the Qur'an, 1989, P. 132

${ }^{14}$ F. Steinggas, Arabic English Dictionary, New Delhi, Cosmo Publications, 1978, P. 379

${ }^{15}$ Al-Magdisi, Al-Qur'an Fath al-Rahman Indexes, Egypt, Mustafa al-Babi al-Halabi, 1322 H, P. 156

${ }^{16}$ M. Hasbi Amirudin, The Concept of an Islamic State According to Fazlur Rahman, Yogyakarta, UII Press, 2000, P. 102

${ }^{17}$ Padmo Wahjono, Pancasila Democracy According to the 1945 Constitution, in Sri Soemantri M and Bintan R Saragih, Indonesian State Administration in Indonesian Political Life, Sinar Harapan, Jakarta, 1993, P. 125
} 
From the formulation as such, the nature of deliberation contains the principles in which among others fall into the following; 1) togetherness in negotiating and solving problems, 2) similarities in conveying interests, 3) tolerance in diverse classes and opinions, and 4) being open to all groups and dynamics that occur in society. ${ }^{18}$

Some models of democracy that have ever taken place in Indonesia such as Pancasila democracy, socialist democracy, or guided democracy have similarities in which they are in the form of consensus / deliberation. Likewise with the founders of Indonesia, when they were about to make a decision in establishing the unitary state of the Republic of Indonesia, they made it by means of consensus / deliberation or agreement between the nationality group and the Islamic group which was incorporated in the Nine Committee formed by BPUPKI.

The result of the consensus / deliberation was Piagam Jakarta (Jakarta Charter) which was later on stipulated by PPKI as the 1945 Constitution of the unitary state of Indonesian Republic on August $18^{\text {th }}, 1945$. This shows that the deliberation undertaken by using Pancasila democracy between Islamic / Non-Islamic groups and nationalist groups was central to the interests of the nation and state to be formed rather than individual or group interests. Thus, deliberation / representation done by the founding fathers of Indonesia was carried out by finding out the point of intersection between Islamic / Non-Islamic religious groups and national / nationalist groups.

Democracy adopted from the west as a democratic system in Indonesia had undergone many changes. That was due to the influence of the democracy culture or the Indonesian popular sovereignty that had been formed and influenced by customary law and Islamic religious law which had taken place when Indonesia was not yet formed. So, the influence of democracy from western philosophy experienced shifts, among others, because it was not in accordance with the lives of the Indonesian people.

As conveyed by Absori et al., in relation to law, humans play a role as both the subjects and the recipients of the mandate to carry out divine laws that have been confirmed and established through revelation (Al-Qur'an) and the Prophet traditions (Sunnah) or hadiths. ${ }^{19}$

This is proven by a shift towards Pancasila and the 1945 Constitution in the constitutional system of the Republic of Indonesia since it was ratified on August 18, 1945

\footnotetext{
18 Andi Pangerang, The Principles of People's Deliberation based on Article 18 of the 1945 Constitution and its Implementation in the Regional Government System, Dissertation, Postgraduate Program of Padjadjaran University, Bandung, 1999, P. 12

${ }^{19}$ Absori, op.cit, P. ix
} 
until today. In history, there had also occurred the emergence of two constitutions that ever prevailed in Indonesia besides the 1945 Constitution, namely the 1949 RIS Constitution and the 1950 Constitution.

As we all know that the democratic ideologies or ideals struggled by the country's founders and leaders of the Indonesian movement ended up with compromise and formulations as set forth in the Preamble to the 1945 Constitution, in which by Hatta, it contained three kinds of fundamental statements; 1) the basic statements of politics and ideals of the Indonesian people, 2) the statements about the success of Indonesian people's political demands, with the gifts from Allah, and 3) the statements as regards Pancasila as the philosophy or ideology of the state, namely belief in the one and only God, humanity, the unity of Indonesia, democracy, and social justice. If observed, Pancasila then has 2 basic things; the first is moral, belief in the one and only God, and the second is politics, namely humanity, Indonesian unity, democracy, and social justice. ${ }^{20}$

The ideal foundation of Pancasila is set forth in the fourth paragraph of the Preamble of the 1945 Constitution as a constitutional foundation, which represents the basic philosophy vis-a-vis the purpose of establishing the Republic of Indonesia. Therefore, anchored in a range of explanations above, it is clear that the democratic election of regional heads needs be understood as democratic values and deliberation in realizing the precepts in Pancasila.

\section{The Deconstruction of Deliberation and Democracy in the Perspective of Pancasila as the Nation's Ideological Foundation.}

Deconstruction is Jaques Derrida's notion. It starts out from Heidegger's thought inferring that we always stay in the language, while Derrida's view is opposite in that we always move in an unstable language. it is because according to him either metaphors or nonmetaphors are ultimately only pairs of semantically opposite words.

The term deconstruction from an etymological viewpoint is actually the same as the definition of analysis, which means to unravel, to open, or to release as derived from the word destruction. ${ }^{21}$ Even though the word or term deconstruction is difficult to define, this term has the value of analysis, or the analysis itself does not mean (destructive), likewise the meaning

\footnotetext{
${ }^{20}$ Moh. Hatta, Our Democracy, Jakarta, PT. Pustaka Antara, 1960, P. 29-30

${ }^{21}$ Absori, op.cit, P. 48
} 
mistakenly understood today. ${ }^{22}$ Thus, it is of importance to be understood that the word deconstruction does not directly relate to the word destruction. It is however connected with the word analysis which etymologically means "to suspend" as it is synonymous with deconstructing.

The tradition of deconstruction in law has developed quite rapidly amid Critical Legal Studies and Feminism of Jurisprudence. Both have the same root wherein they are intensively working to develop a model of deconstruction method in an effort to understand the reality of law which is experiencing a very rapid development as well. ${ }^{23}$

Balkin provides an illustration when translating the relationship of Derrida's deconstruction with law, namely: 1) the presence of a methodological conception to deeply criticize legal doctrines, 2) being able to explain how legal arguments differ from ideologies, 3 ) offering a new way of interpreting legal texts, and 4) ideas about free play of the text ${ }^{24}$.

Therefore, the basic deconstruction according to Derrida is that deconstruction is not a means of solving "an individual or collective subject that takes the initiative and applies it to a particular object, text, or theme". Deconstruction is an event that does not await consideration, awareness, or organization of a subject or even modernity.

The definition of ideology is the overall views of ideals, values, and beliefs that want to be realized in a concrete reality of life. ${ }^{25}$ Ideology, by sociologists and political scholars, is said to have a negative influence. This is in light of that ideology is understood to be the same as a political concept or propaganda that contains certain power interests. However, ideology is needed by a country when it feels the presence of powerful threats from other countries.

As guidance to state life, ideology can unite, provide formulation of the state situation in the past time, present time, and set strategic steps to achieve the desired situation. Ideology provides the rules for political and societal lives in a joint effort to reach national welfare as a strong unity. ${ }^{26}$

\footnotetext{
${ }^{22}$ Anton F. Susanto, Law from Consilience to Constructive-Transgressed Legal Paradigm, PT. Refika Aditama, Bandung, $2017,2^{\text {nd }}$ Print (revised), P. 181

${ }^{23}$ Ibid.

${ }^{24}$ Otje Salman and Anton, Legal Theory: Remembering, Gathering, and Reopening, Ed. Iman Taufik, PT. Refika Aditama, Bandung, 2017, P. 127-128, in Absori et al., Prophetic Legal Paradigm: The Criticism of the Non-Systemic Legal Paradigm, Genta Publishing, $1^{\text {st }}$ Print, Yogyakarta, 2015, P. 49

${ }^{25}$ Soerjanto Poespowardojo, Pancasila as an Ideology Viewed from the Viewpoint of Life Together, in Alfian \& Oetojo Oesman, eds. Pancasila as an Ideology in Various Fields of Community, National and State Life, Jakarta : BP-7 Pusat, 1991, P. 44

${ }^{26}$ Paulus Wahana, The Philosophy of Pancasil, Kanisius, Yogyakarta, 1993, P. 83,Dahlan Thaib, Indonesian State Administration; Constitutional Perspective, Total Media, Yogyakarta, 1st Print, 2009. P. 10
} 
Ideology, in accordance with Edward Shils, ${ }^{27}$ has the characteristic of being a straightforward formulation of various problems; it has binding principles for its followers; and it revolves around one basic value as a core. The nature of ideology is comprehensive, and it falls into nine characteristics, namely: 1) straightforward formulation, 2) intentionally integrated around a moral or cognitive belief, 3) recognizing its relation to past and present patterns, 4) closing the entry of new elements or variations, 5) the necessity to do it in an attitude, 6) the behavior and actions of its adherents, 7) the existence of a pleasure feeling towards the ideology, 8) the necessity of consensus from all of its followers, 9) being legalized into law and connected with a body established to uphold the patterns of the ideology.

Thus, ideology can be said to be a process of maturity in social, national, and state lives organized as an order. In the system of philosophy, it can be said that ideology is as the center of relations in the life of the nation and state so that ideology can unite pluralism or differences in order to achieve the goals and welfare of the nation.

Saafrudin Bahar stated that ideology has advantages and disadvantages. It is advantageous because its nature is comprehensive and consistent, and it is able to provide solid answers to various problems encountered. While, it is also disadvantageous because its comprehensive nature tends to close itself to everything that is not in accordance with the value system it adopts. Hence, such condition leads to being dogmatic, rigid, and intolerant of other parties or of new facts that are not in accordance with the value system that is followed and standardized as a legal system. ${ }^{28}$

In the reform era, lots of questionings were posed about the ability of Pancasila ideology as the stance, adhesive, and pillar supporting the life of the nation and state. This then led to other more promising ideologies, and even the state administrators and the people whose thoughts and behavior were pragmatic unwittingly moved away from the values as contained in the ideology of Pancasila. Pancasila has no longer been placed as an ideology in carrying out the life of the nation and state. ${ }^{29}$

This phenomenon happens due to the negative influence of globalization on the ideology of Pancasila, so that it can be a quite dangerous threat to the country. The ease of

\footnotetext{
${ }^{27}$ Edward Shils, "Ideology" in the International Encyclopedia of The Social Science, Vol. 7, New York, The MC Millan Company \& The Free Press, 1972, P. 66-76

${ }^{28}$ Saafrudin Bahar, Pancasila as an Ideology in the Security Defense Life of Pancasila, Editor: Oetoyo Usman, Alfian, BP-7 Pusat, 1996, P. 335-336

${ }^{29}$ Absori, The Ideals of Pancasila Law, Various Paradigms of Identity-based Law of Indonesia, Kartasura, Solo, Pustaka + Iltizam, 2016, P. 8
} 
building relationships among countries leads to the ease of undergoing negative influences from outside that enter Indonesia as well. The influence will gradually have an unwittingly bad impact on the character of society, whereby the influence as such is not in accordance with the character of the nation, and this is what is happening in Indonesia today.

Besides, Pancasila as an open ideology is an ideology that is able to deal with the development of era as dynamics within society. Therefore, the basic values of Pancasila ideology should be maintained, while their realization through legislation can be implemented by always following the development of the community.

According to Prof. Satjipto jurisprudence is often understood in a superficial and narrow way and merely viewed from its surface without reaching the essential aspects of the jurisprudence itself. In his viewpoint, when the development of jurisprudence is seen, its progress is far left by the object ruled by jurisprudence. In his view, the aspects of ontology, epistemology, and axiology of jurisprudence do not satisfy his thoughts because in general the approaches to understanding law are often linear with conventional main streams. Often, with the clear idea, Prof. Satjipto incorporates transcendent elements in understanding law. And, his analysis nuances another color compared to the habits commonly practiced by legal scientists in Indonesia. ${ }^{30}$

Therefore, according to Prof. Satjipto Raharjo, Indonesia needs a type of progressive law enforcement as can be seen in empirical observations. Even though people demand the presence of law rules, the implementation of law in fact does not generate the expected results. Abuse of authority occurs in almost every linear bureaucracy at the levels of both the central government and the regional government. ${ }^{31}$

However, Bagir Manan's view states that a state which is based on law implies that the power is limited by law, and at the same time it states that law is supreme compared to all of the existing instruments of power. ${ }^{32}$ In other words, the state places the law as the basis of its power, and the implementation of any form of power is carried out under the rules of law. ${ }^{33}$

\footnotetext{
${ }^{30}$ Khudzaifah Dimyati, Progressive Legal Thoughts: In the Shadows of the Positivistic Thought Tradition, This Paper is presented at the Seminar of Progressive Law organized by the Consortium of Progressive Law, Satjipto Rahardjo Institute, with the theme: "The Deconstruction of the Progressive Legal Thought Movement", Semarang, 29-30th of November 2013 ${ }^{31}$ Satjipto Rahardjo, Indonesia Demands Progressive Law Enforcement, Kompas, July $15^{\text {th }} 2002$, in Khudzaifah Dimyati, Progressive Legal Thoughts: In the Shadows of the Positivistic Thought Tradition, This Paper is presented at the Seminar of Progressive Law organized by the Consortium of Progressive Law, Satjipto Rahardjo Institute, with the theme: "The Deconstruction of the Progressive Legal Thought Movement", Semarang, 29-30th of November 2013

${ }^{32}$ Bagir Manan and Kuntana Magnar, A number of Indonesian Constitutional Law Issues, Bandung, Alumni, 1993, P. 128

${ }^{33}$ A. Hamid S. Attamimi, Indonesian Legislative Theories (A Side of the Indonesian Legislative knowledge Explaining and Clearing Understanding), Inauguration Speech of Permanent Professor, the Faculty of Law at the University of Indonesia, Jakarta, 1992, P. 8
} 
H.L.A.Hart ${ }^{34}$ distinguishes the meaning of "positivism" as is often referred to in contemporary jurisprudence, namely: first, the notion that laws are human commands; second, the assumption that there is no need for a relationship between laws and morals or the existing laws and those that are supposed to exist; third, the assumption that the analysis (study of meaning) of legal conceptions: (a) deserves to be continued; and (b) must be distinguished from historical studies in regard to the causes or origins of laws, from sociological studies with respect to the relationship of laws with other social phenomena, and from critique or legal appreciation whether it is in a moral sense or vice versa; fourth, the assumption that the legal system is a logical system that is closed. It means that the right legal decisions can be produced by logical means pursuant to the predetermined legal regulations without taking account of social demands, policies, and moral norms; fifth, the assumption that moral judgments cannot be given or maintained, as is the case with statements about facts, with rational reasons, instructions, or evidence.

Different from Donald Black's view drawing on that changes in law occur because of the people's movement in carrying out the law. Therefore, the understanding and sociological analysis are increasingly moving forward to dissect the practices, processes, and institutions existing in society. ${ }^{35}$

From discerning several views related to the development of jurisprudence, it is understood that power in the state needs to be limited by law, as stated by Lord Acton, governance is held by humans, and within human beings without exception, many weaknesses are attached. This is because humans have unlimited power so that the power tends to be misused. ${ }^{36}$

In facing the era of globalization, the ideology of Pancasila in the national consensus represents an agreement of all Indonesian people as set forth in in the Proclamation of August $17^{\text {th }}, 1945$ and then described in the Preamble of the 1945 Constitution. This ideology is highly needed to face the problems and understanding of various aspects of national and state lives.

\footnotetext{
${ }^{34}$ W. Friedmann, Legal Theory. New York: Columbia University Press, P. 256-257 in Khudzaifah Dimyati, Kelik Wardiono, The Patterns of Responsive Legal Thoughts: A Study on the Indonesian Legal Science Development Process, Journal of Legal Studies, UMS, Vol. 10, No. March 1, 2007

${ }^{35}$ Donald Black, Sociological Justice, Oxford University Press, New York, 1988, P. 102-13.

${ }^{36}$ Miriam Budiardjo, The bases of Political Science, Jakarta, Gramedia, 1996, P. 52
} 


\section{The Deconstruction of Deliberation / Representation in the Perspective of Regional Head Election as an Implementation of Pancasila.}

According to Hans Kelsen, basically democracy is the government by the people and for the people. With the acceptance of Kelsen's description as regards the basis of democracy, it can now be answered that;

1) Those who execute the democratic state power are the elected representatives wherein the people are convinced that all of their wishes and interests will be taken into account in carrying out the state power.

2) The way to execute the democratic state power is by always remembering the people's wishes and desires so that every action in carrying out the state power is not contrary to the wishes and interests of the people. In this sense, the state power makes an effort to fulfill all wishes of the people.

3) The amount of the power of a democratic state that can be executed cannot be determined by numbers, but as much as possible to obtain the results desired by the people as long as the power implementation does not deviate from the basic principles of democracy. ${ }^{37}$

A state which bases on the values of popular sovereignty or democracy draws on the meaning that the people are the strength of the country. Democracy is used as the basis of state life which gives an understanding that at the last stage the people are the givers of provisions in the matters in regard to national and state life. This is because the establishment of a country is based upon the people's desire.

In social contract theory or social agreement theory, it is assumed that the agreement is the basis of the state. The community formed is based upon the community agreements. Thomas Hobbes states that there is only one type of agreement, namely pactum subjectionis or the government agreement with individuals who promise to give all natural rights they have to a person or a group of people appointed to govern their lives. Besides, the person or group of people appointed is also given power. ${ }^{38}$

As we all know, the notion or idea of popular sovereignty became a concept which was later stated in the 1945 Constitution. The idea as such was emerged from the progressive dialogue amongst the figures of the state founding movement towards the moment of the

\footnotetext{
${ }^{37}$ C.S.T. Kansil and Christine S.T. Kansil, State Science, Jakarta, PT Pradnya Paramita, Second edition, 2004, P. 114

${ }^{38}$ Hobbes, Thomas, Leviathan, England, Penguin Classics, 1985
} 
Indonesian Republic independence on August $17^{\text {th }}, 1945$. Then it was agreed to be set forth in the 1945 Constitution by stating that the Republic of Indonesia was a State based upon popular sovereignty.

Even though it is said that popular sovereignty or democracy does not necessarily be carried out as it really means, democracy is a process of following the development of society. The development of democracy in Indonesia until after the changes to the 1945 Constitution had experienced a good development.

The people's aspirations in the various regions, different potential of each region, and different situation in each region have the potential to give specificity to those regions. Therefore, a view that generalizes capabilities and conditions in each region is impossible. ${ }^{39}$ This is considering the vast territory and diversity of cultures and religions existing in Indonesia.

One of the forms of autonomy granted to the Indonesian regions was that of 2004, and there has been a change since that year. The election of regional heads has been directly elected by the people. This is in line with changes in the 1945 Constitution to Article 18 concerning with Government in regions. As stipulated in Law 32/2004 Article 24 (5), that "regional heads and deputy regional heads as referred to in paragraph (2) and paragraph (3) in a pair are directly elected by the people in the areas concerned."

The amendment to article 18 of the 1945 Constitution has made a change from the indirect election of regional heads (representatives) to the direct election of regional heads by the people. The change as such is a form of deconstruction in people's deliberation for the sake of providing welfare, benefits, and political power to the people in regions.

In its development, the elections of regional heads and the deputies (Pilkada) are undertaken simultaneously with the aim of efficiency as well as minimizing the occurrence of conflicts over the implementation of the elections. Direct elections have been conducted since 2005. Even, the first simultaneous execution of Pilkada was carried out on the $9^{\text {th }}$ of December 2015. However, the forms of regional head elections that ever prevailed in Indonesia were inseparable from money politics. Thus, not a few of the regional heads elections generated the leaders whose leadership was merely implemented based upon their own interests. This is due to educational and economic factors that affect the elections.

\footnotetext{
${ }^{39}$ Sjachran Basah, Three Articles on Law, Bandung Armico, 1986, P. 36
} 
Actually, the regional heads need not to be elected by either the Regional People's Representative Council (DPRD) or the people, especially for those at the Provincial level. The election of regional heads at the provincial level can be conducted by the President. This is because the provincial heads play a role as an extension of the executive at the central government level.

Democracy reflected in the fourth precept of the Pancasila "democracy guided by the inner wisdom in the unanimity arising out of deliberations amongst representatives" contains several features in the realm of democratic thought in Indonesia. The Preamble to the 1945 Constitution states that sovereignty is based on "the populace" and "deliberation". Accordingly, democracy contains some characteristics: (1) the populace (popular sovereignty), and (2) deliberation (kinship). In this regard, Sukarno believed that an absolute requirement for the strength of the Indonesian state was the deliberative representation. Mohammad Hatta added that the populace embraced by the Indonesian people was not the populace seeking the most votes, but the populace led by wisdom in the deliberative representation. Therefore, Indonesian democracy is neither a liberal democracy nor a totalitarian democracy because it relates thoroughly to other Pancasila principles. ${ }^{40}$

Therefore, the President as the head of government directly elected by the people plays a role as the people's representative to determine the regional heads at the provincial level. That the President elects the regional heads is a form of the implementation of "democracy guided by the inner wisdom in the unanimity arising out of deliberations amongst representatives". The regional heads at the provincial level is the regional coordinators in regencies and cities. This is because regions are inseparable parts of the unitary state of the Indonesian Republic. Thus, the elections of regional heads and the deputies should be closely related to the election of president and the deputy as holders of governmental power as stated in Article 4 paragraph (1) of the 1945 Constitution. In this point, they do not need to be elected by the people.

Popular sovereignty or democracy in Indonesia is formulated as Pancasila democracy. The implementation of democracy is based on, among other things, the rules (Constitution), institutions, and governmental systems that rest upon democracy in the consultative / representative system.

\footnotetext{
${ }^{40}$ Soekarno in Yudi Latif, Plenary State: Historicity, Rationality, and Actuality of Pancasila, Jakarta: Gramedia Pustaka Utama, 2011, P. 476
} 
Deconstruction emphasizes the return of perspective in seeing the meaning of something by viewing the more essential points from the doctrine that has been sacred in the time span / history. Deconstruction is also interpreted as dismantling hegemony that has been considered as establishment of power. As also expressed by Jacques Derrida, a law is no longer fixed on expressions and meanings because the differences tend to be floating. Therefore, it is necessary to change the sign and meaning that is not reflected as an established code but creative code without limits. ${ }^{41}$

The reform era of the 1945 Constitution experienced the amendment four times. The amendment that was made rested upon a public demand because the implementation of popular sovereignty and the value of deliberation were in conflict with the Pancasila and the Preamble of the 1945 Constitution. In this case, with changes in the 1945 Constitution, it would conform to the historical values of the struggle for the embodiment of the unitary state of Indonesian Republic.

Thus, deconstruction has dismantled modernism which has so far been considered as the truth in the field of law by modern society. The conception of legal truth is an extremely important value indicating relative and vague tendencies. The value of truth is understood by using different views and leads to an understanding that the truth is measured according to the perception of lawmakers. Lawmakers are based upon the willingness of the authorities supported by the majority of political groups set forth in the form of laws. In fact, the will and political views of the majority of groups do not necessarily reflect the truth. ${ }^{42}$

\section{CONCLUSION}

Anchored in the above explanations, a conclusion can be drawn that the unitary state of Indonesian Republic is a country that adheres to the understanding of democracy, in which the people participate in determining the course of government and the direction of development. As a country whose territory and society are plural, this condition makes Indonesia use indirect democracy or democracy with a representative system.

Indonesia is one of the countries in the world whereby in carrying out the life of the nation and state, it cannot be separated from using the principle of democracy as a

\footnotetext{
${ }^{41}$ Absori, et al., loc.cit, Prophetic Legal Paradigm: The Criticism of Non-Systemic Legal Paradigm, P. Viii)

42 Absori, The Epistemology of Transcendental Law and Its Implementation in the Development of the Doctoral Program of Legal Studies, Presented at the National Seminar with the theme "Developing the Epistemology of Legal Studies", The 11 ${ }^{\text {th }}$ of April 2015 at Muhammadiyah University of Surakarta)
} 
manifestation of community participation in the administration of state life. This point is stated in the Preamble to the 1945 Constitution which is then elaborated in the formulation of the 1945 Constitution articles as the values of popular sovereignty.

Over time, the administration of government in Indonesia is felt not to reflect democratic values, so the Indonesian people make a change. This is in order that the 1945 Constitution as a source of state administration is changed as necessary for the sake of generating a more democratic government.

The implementation of the direct local elections chosen by the Indonesian people which has been going on since 2005, although they have not yet generated regional heads with good leaderships, the efforts to form a democratic government are continuously made. This is as mandated by Article 18 paragraph (4) of the 1945 Constitution which implies that the regional heads are elected democratically.

Therefore, the democratic meaning in Article 18 paragraph (4) of the 1945 Constitution is not limited to being elected directly or indirectly by the people. Local elections can be carried out in accordance with the national identity of Indonesia. As the meaning of democracy, it contains the basic values of government from the people, by the people, and for the people. In accordance with the meaning of democracy conveyed by Abraham Lincoln, the $16^{\text {th }}$ President of the United States (Period 1861-1865), democracy is simply interpreted as "the government from the people, by the people, and for the people".

Thus, the deconstruction of democracy in the implementation of the Pancasila precepts extends to that on one side democracy is as a modern socio-political system that prioritizes the interests or power of the authorities that are positioned as representatives of the people. On the other side, in prophetic values, humans are the part of the state, so in solving all problems that exist in humans' lives, in the lives of either individuals or nation, they are limited by God's sovereignty. This is as stated in the first precept of Pancasila and as decomposed in Article 29 paragraph (1) of the 1945 Constitution. In this case, God's rules are in the supreme position, and the will of the people as a state goal is in accordance with the Divine will. 


\section{REFERENCES}

\section{Books}

Absori, et al, Prophetic Legal Paradigm: The Criticism of Non-Systemic Legal Paradigm, Yogyakarta, Genta Publishing, the First Print, 2015.

, The Ideals of Pancasila Law, Various Paradigms of Identity-based Law of Indonesia, Kartasura, Solo, Pustaka + Iltizam, 2016.

Agussalim Andi Gadjong, Local Government; the Study of Politics and Law, Bogor, Ghalia Indonesia, 2007.

Al-Magdisi, Al-Qur'an Fath al-Rahman Indexes, Egypt, Mustafa al-Babi al-Halabi, $1322 \mathrm{H}$.

Alfian \& Oetojo Oesman, eds. Pancasila as an Ideology in Various Fields in the Lives of Community, Nation, and State, Jakarta: BP-7 Pusat, 1991.

Anton F. Susanto, Non Systemic Jurisprudence, The Philosophical Foundation of Indonesian Jurisprudence Development, Yogyakarta, Genta Publishing, 1st Print, 2010.

, Law from Consilience to Constructive-Transgressed Legal Paradigm, Bandung, PT. Refika Aditama, 2nd Print (revised), 2017.

A.S Hornby,Oxford Advanced Learned Dictionary, Oxford University Press, Fourth Edition 1989.

Bagir Manan and Kuntana Magnar, A number of Indonesian Constitutional Law Issues, Bandung, Alumni, 1993

C.S.T. Kansil and Christine S.T. Kansil, State Science, Jakarta, PT Pradnya Paramita, Second edition, 2004.

Dahlan Thaib, Indonesian State Administration; Constitutional Perspective, Total Media, Yogyakarta, 1st Print, 2009.

Donald Black, Sociological Justice, New York, Oxford University Press, 1988.

Edward Shils, "Ideology" in the International Encyclopedia of The Social Science, Vol. 7, New York, The MC Millan Company \& The Free Press, 1972.)

F. Steinggas, Arabic English Dictionary, New Delhi, Cosmo Publications, 1978.

H, Mahmud Yunus, Indonesian Arabic Dictionary, Jakarta, The Foundation for Translator / Interpreter of the Qur'an, 1989.)

Hobbes, Thomas, Leviathan, England, Penguin Classics, 1985.

Janedjri M. Gaffar, Constitutional Democracy of Indonesian Constitutional Practices after the Amendment of the 1945 Constitution, Jakarta, Constitution Press, 2013. 
Jimly Asshiddiqie, Towards a Democratic Law State, Jakarta, PT Bhuana Ilmu Populer, Gramedia Group, 2009.

Miriam Budiardjo, The bases of Political Science, Jakarta, Gramedia, 1996.

M. Hasbi Amirudin, The Concept of an Islamic State According to Fazlur Rahman, Yogyakarta, UII Press, 2000.

Moh. Hatta, Our Democracy, Jakarta, PT. Pustaka Antara, 1960.

M. Quraish Shihab, Insights of the Qur'an, Bandung, Mizan, Second Print, 1996.

Saafrudin Bahar, Pancasila as an Ideology in the Security Defense Life of Pancasila, Editor: Oetoyo Usman, Alfian, BP-7 Pusat, 1996.

Sjachran Basah, Three Articles on Law, Bandung Armico, 1986.

Sri Soemantri M and Bintan R Saragih, Indonesian State Administration in the Indonesian Political Life, Jakarta, Sinar Harapan, 1993.

Zein Badudu, General Dictionary of Indonesian Language, Jakarta, Pustaka Sinar Harapan, 1st Print 1994.

\section{Journal Articles}

Khudzaifah Dimyati, Kelik Wardiono, The Patterns of Responsive Legal Thoughts: A Study on the Indonesian Legal Science Development Process, Journal of Legal Studies, UMS, Vol. 10, No. March 1, 2007

Muhammad Hanafi, The Position of Deliberation and Democracy in Indonesia, Jurnal Cita Hukum, The Faculty of Syari'ah and Law of UIN Syarif Hidayatullah, Jakarta, Vol. 1, No. 2, December 2013

\section{Papers}

Absori, Epistemology of Transcendental Jurisprudence and Its Implementation in the Development of the Doctoral Program of Legal Studies, Presented at the National Seminar with the theme "Developing the Epistemology of Legal Studies", April 11 2015 at Muhammadiyah University, Surakarta.

A. Hamid S. Attamimi, Indonesian Legislative Theories (A Side of the Indonesian Legislative knowledge Explaining and Clearing Understanding), Inauguration Speech of Permanent Professor, the Faculty of Law at the University of Indonesia, Jakarta, 1992.

Khudzaifah Dimyati, Progressive Legal Thoughts: In the Shadows of the Positivistic Thought Tradition, This Paper is presented at the Seminar of Progressive Law organized by the Consortium of Progressive Law, Satjipto Rahardjo Institute, with the theme: "The 
Deconstruction of the Progressive Legal Thought Movement", Semarang, 29-30th of November 2013

\section{Doctoral Dissertation}

Andi Pangerang, The Principles of People's Deliberation based on Article 18 of the 1945 Constitution and its Implementation in the Regional Government System, Dissertation, Postgraduate Program of Padjadjaran University, Bandung, 1999 